\title{
Milk consumption during pregnancy increases birth weight, a risk factor for the development of diseases of civilization
}

\author{
Bodo C Melnik ${ }^{1 *}$, Swen Malte John ${ }^{1}$ and Gerd Schmitz ${ }^{2}$
}

\begin{abstract}
Antenatal dietary lifestyle intervention and nutrition during pregnancy and early postnatal life are important for appropriate lifelong metabolic programming. Epidemiological evidence underlines the crucial role of increased birth weight as a risk factor for the development of chronic diseases of civilization such as obesity, diabetes and cancer. Obstetricians and general practitioners usually recommend milk consumption during pregnancy as a nutrient enriched in valuable proteins and calcium for bone growth. However, milk is not just a simple nutrient, but has been recognized to function as an endocrine signaling system promoting anabolism and postnatal growth by activating the nutrient-sensitive kinase mTORC1. Moreover, pasteurized cow's milk transfers biologically active exosomal microRNAs into the systemic circulation of the milk consumer apparently affecting more than 11000 human genes including the mTORC1-signaling pathway. This review provides literature evidence and evidence derived from translational research that milk consumption during pregnancy increases gestational, placental, fetal and birth weight. Increased birth weight is a risk factor for the development of diseases of civilization thus involving key disciplines of medicine. With regard to the presented evidence we suggest that dietary recommendations promoting milk consumption during pregnancy have to be re-evaluated.
\end{abstract}

Keywords: Birth weight, Exosomal microRNA, Fetal weight, Gestational weight, Milk, mTORC1, Placental weight, Primary prevention

\section{Introduction}

To meet the requirements for macronutrients and minerals during pregnancy gynecologists and general practitioners recommend increased servings of milk and dairy products [1]. Although milk is a rich source of essential amino acids and calcium, recent understanding of milk's biological function has changed during the last years. Milk is not just a nutrient, but represents an endocrine signaling system of mammals activating the key regulator of cell growth and anabolism, the nutrient-sensitive kinase mTORC1 (mechanistic target of rapamycin complex 1) [2]. At the molecular level, cell growth, proliferation, and anabolism are regulated by mTORC1 [3-12]. In the perspective of human evolution, persistent cow's milk consumption is a novel human behavior, which

\footnotetext{
* Correspondence: melnik@t-online.de

${ }^{1}$ Department of Dermatology, Environmental Medicine and Health Theory, University of Osnabrück, Sedanstrasse 115, D-49090 Osnabrück, Germany Full list of author information is available at the end of the article
}

may result in long-term adverse health effects [13]. Increased mTORC1 signaling during milk consumption has recently been confirmed in a rodent model and has been associated with the development of obesity [14-17]. Pregravid maternal overweight and obesity are wellknown risk factors that promote fetal overnutrition and fetal macrosomia [18-26]. Increased birth weight is a risk factor for the development of diseases of civilization, especially obesity $[22,23,25]$. To understand the impact of milk consumption on fetal growth, it is of critical importance to appreciate milk's biological function as an activator of mTORC1 and transmitter of gene-regulatory exosomal microRNAs [2].

\section{Pivotal mTORC1-activating signals}

mTORC1 orchestrates cell growth and proliferation [3]. mTORC1 is the central hub of metabolism that activates nucleotide, protein and lipid synthesis under conditions of 
nutrient and growth factor availability [3-12]. mTORC1 plays a fundamental role in cell cycle control and cell growth [27], protein and lipid synthesis [7,12], lipid accumulation and adipogenesis [28,29]. Thus, persistently overactivated mTORC1 signaling stimulates weight gain, increases body mass, and fat mass $[14,29,30]$.

Basically, there are five major pathways, that activate mTORC1: 1) the presence of growth factors such as insulin and IGF-1 $[3,6,7,11,12], 2)$ sufficient cellular energy (glucose, ATP) [31,32], 3) the availability of amino acids, predominantly essential branched-chain amino acids (BCAAs) such as leucine [5-10,33], 4) the presence of glutamine for cellular leucine uptake and glutaminolysismediated activation of mTORC1 [34-36], and 5) the availability of saturated fatty acids, especially palmitic acid [37].

\section{Milk provides all signals for mTORC1-activation}

Mammalian evolution relies on lactation and its secretory end-product milk, required and sufficient for postnatal growth. Milk is not just a simple nutrient, but represents a sophisticated postnatal endocrine system providing all signals that are required to activate MTORC1 of the milk recipient, physiologically the newborn mammal [2].

\section{Essential branched-chain amino acids activate mTORC1}

Milk proteins provide highest amounts of essential BCAAs, especially leucine [38]. Leucine plays a pivotal role for activating mTORC1 (Figure 1) [33]. Of all animal proteins, whey proteins contain the highest amount of leucine (14\%) [38], and in comparsion to meat $(8 \%$ leucine), whey proteins undergo fast intestinal hydrolysis, thus operate like an i.v. amino acid infusion [39-42].

\section{Glutamine activates mTORC1}

Milk protein ( $8.09 \mathrm{~g}$ glutamine/100 g) in comparison to beef protein ( $4.75 \mathrm{~g}$ glutamine $/ 100 \mathrm{~g})$ provides $70 \%$ more glutamine [43]. Glutamine is an important activator of mTORC1 via its function as a gatekeeper for cellular leucine uptake and via its precursor function in the glutaminolysis pathway that activates mTORC1 (Figure 1)

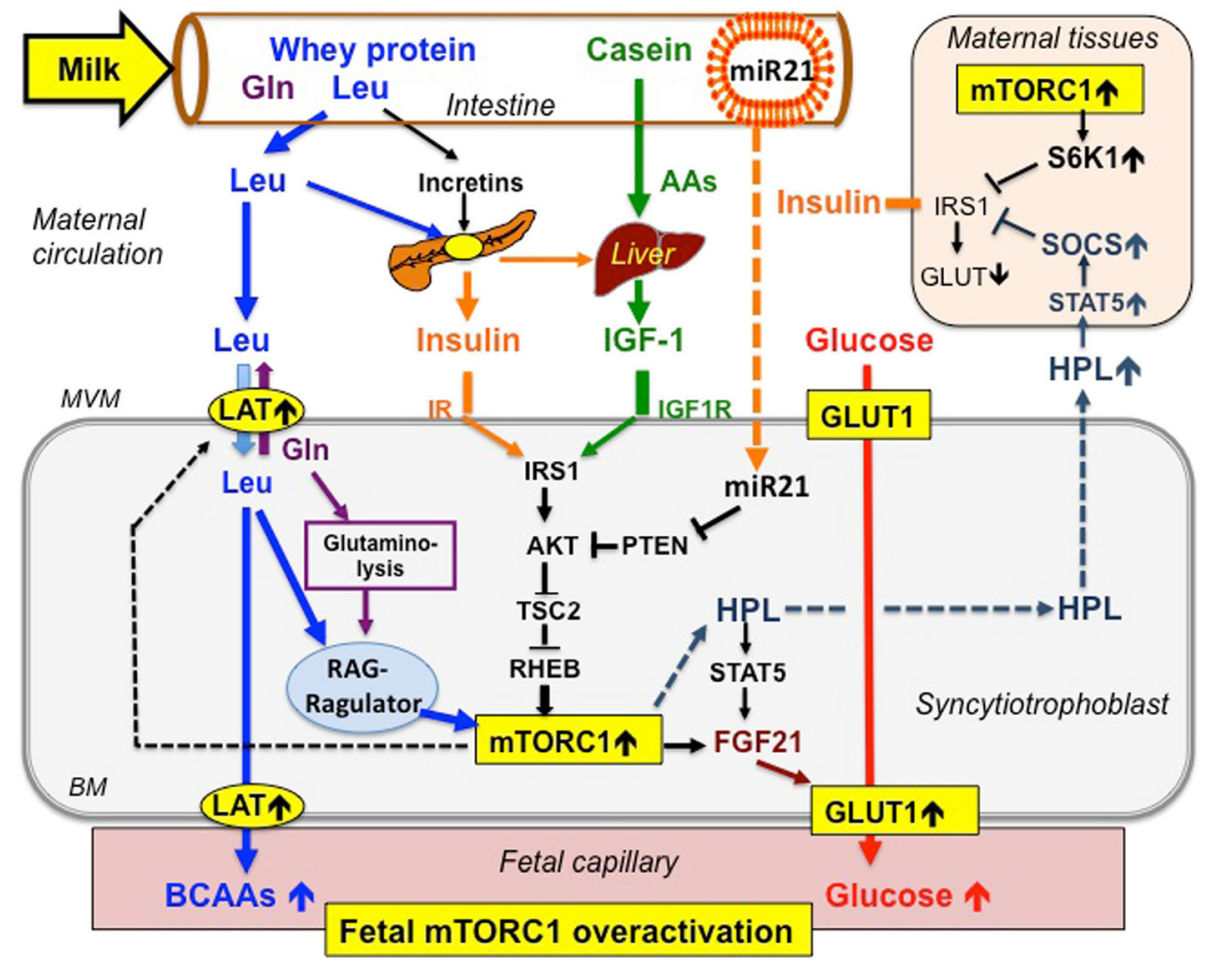

Figure 1 Interactions between milk and trophoblast mTORC1 signaling. Leucine (Leu) and glutamine (GIn) derived from whey protein hydrolysis increase serum insulin. Milk casein increases serum IGF-1. Leucine, insulin and IGF-1 stimulate trophoblast mTORC1. Milk consumption is associated with placental weight gain, which is related to increased serum levels of human placental lactogen (HPL). HPL via STAT5/SOCS signaling as well as increased milk-mediated mTORC1/S6K1 signaling induce insulin resistance enhancing the glucose gradient to the fetus. Increased trophoblast mTORC1 and HPL stimulate placental expression of FGF21 upregulating GLUT1. Milk consumption during pregnancy exaggerates glucose transfer to the fetus. Trophoblast mTORC1 stimulates the expression of L-type amino acid transporters (LAT) (dotted line). Thus, milk intake during pregnancy overstimulates diaplacental flux of glucose and BCAAs promoting mTORC1-driven fetal overgrowth. Bovine exosomal microRNA-21 (miR-21) reaches maternal circulation and may thus decrease trophobast PTEN expression thereby enhancing trophoblast mTORC1 signaling. 
[44-46]. Leucine is an allosteric activator of glutamate dehydrogenase (GDH), the key-regulating enzyme of the glutaminolysis pathway $[44,45]$. The interplay of glutamine and leucine maximizes the flux through GDH in pancreatic $\beta$-cells, which is important for mTORC1S6K1-dependent insulin secretion [46].

\section{Insulin activates mTORC1}

Milk stimulates insulin secretion (Figure 1) [2]. The insulinemic index of whole cow's milk $(148 \pm 14)$ and skim milk $(140 \pm 13)$ is much higher than the glycemic indices of whole milk (42 \pm 5$)$ and skim milk $(37 \pm 9)$, respectively $[47,48]$. Fast hydrolysis and immediate intestinal absorption of insulinotropic amino acids of the whey protein fraction of cow's milk raises insulin levels to much higher magnitudes than intestinal digestion of structural proteins such as beef (insulinemic index: 51 ) $[47,48]$. The major insulinotropic protein fraction of cow's milk is the whey protein fraction [49]. Whey-derived leucine and other whey-derived amino acids stimulate incretin secretion of enteroendocrine K- and L-cells [50-54]. Additionally, whey-derived amino acids directly exert inulinotropic effects on pancreatic $\beta$-cells [55-57]. Milk protein consumption in comparison to meat protein intake thus results in hyperinsulinemia [58].

\section{Insulin-like growth factor-1 activates mTORC1}

A meta-analysis confirmed that continued milk consumption increases serum levels of insulin-like growth factor-1 (IGF-1) [59]. The European Prospective Investigation into Cancer and Nutrition confirmed a relationship between milk intake in 2109 European women with increased IGF-1 serum levels [60]. A 20\% increase in serum IGF-1 levels has been observed in prepubertal children previously not used to milk consumption after a daily intake of $710 \mathrm{~mL}$ of milk for 4 weeks [61]. A recent study including 193 overweight adolescents aged 12-15 years drank either $1 \mathrm{~L} /$ day of skimmed milk, whey, casein or water for 12 weeks. All milk-baseddrinks contained $35 \mathrm{~g}$ milk protein/L. IGF-1 significantly increased with skimmed milk and tended to increase with casein compared to the pre-test control group [62]. Casein in comparison to whey protein has been shown to differentially enhance hepatic IGF-1 synthesis [49]. Notably, per capita cheese consumption, the major dairy source of casein, increased in Germany from $5 \mathrm{~kg}$ in 1950 to $24.4 \mathrm{~kg}$ in 2013 [63].

\section{Palmitic acid activates mTORC1}

Cow's milk contains about 3.5 to $5 \%$ total lipid. About $98 \%$ of the lipid is composed of triacylglycerol, transported in milk fat globules [64]. The major fatty acid of total fatty acids of milk lipids is palmitate (C16:0) with 32.3 wt\% $[64,65]$. Palmitate like BCAAs activates mTORC1 [37].

Thus milk, the promoter of postnatal growth of mammals, activates mTORC1 of the milk recipient either by transfer or induction of critical mTORC1 activating signals (Figure 1).

It is the intention of this review to demonstrate that milk consumption during pregnancy increases weight trajectories of the growing human fetus promoting increased birth weight, a well-known risk factor for the development of diseases of civilization.

\section{Milk consumption and pregravid maternal weight}

Prepregnancy maternal overweight and obesity are risk factors promoting fetal overnutrition and macrosomia [18-26]. Obesity is associated with enhanced TORC1 signaling [14-16]. In obesity serum levels of insulin, BCAAs, and free palmitate are increased [66-69]. In obese children additional supply of leucine resulted in excessive hyperinsulinemia [70]. Elevated serum levels of BCAAs in children and adolescents have been identified as predictors of insulin resistance [69]. Notably, milk protein but not meat protein consumption induced hyperinsulinemia and insulin resistance [58]. In obesity and states of insulin resistance, palmitate serum levels are significantly elevated [71-73]. Milk-mediated stimulation of mTORC1 increases the phosphorylation of the major mTORC1 substrate, S6 kinase 1 (S6K1) [14]. Overactivated S6K1 via phosphorylation of insulin receptor substrate-1 (IRS-1) is a pivotal mechanism that induces insulin resistance $[74,75]$.

There is substantial evidence that milk consumption in children increases linear growth and body mass index (BMI) [76-78], increases BMI in adolescents, and adults [79-81]. Noteworthy, a recent meta-analysis of Chen et al. [82] including 29 randomized controlled trials found no significant effects of total dairy intake on body weight and body fat [82]. Notably, this study did not differentiate between milk and other processed milk products. The study of Abreu et al. [83] reported a protective association between dairy product consumption and abdominal obesity among Azorean boys. However, this study using a self-administered semiquantitative food frequency questionnaire (categorizing $<2$ and $\geq 2$ servings per day) did not discriminate between the effects of milk consumption versus other dairy products and did not provide quantitative dose-response data on daily milk intake. By using the same semiquantitative food frequency questionnaire methodology categorizing the number of servings/day the authors reported an inverse association between milk intake and both BMI and body fat in 583 Azorean girls but not in 418 Azorean boys [84]. In contrast, Arnberg et al. [80] investigated 203 overweight adolescents with a BMI of $25.4 \pm 2.3 \mathrm{~kg} / \mathrm{m}^{2}$ (mean $\pm \mathrm{SD}$ ), who received an additional daily amount of 
$35 \mathrm{~g}$ milk protein either as $1 \mathrm{~L} /$ day of skim milk, whey, or casein, or water as a control for 12 weeks. BMI-forage Z-score was greater at 12 weeks in the skim milk, whey, and casein groups compared with baseline and the control groups [80]. Remarkably, the National Health and Nutrition Examination Survey (NHANES) data from 1999 to 2004 including 1,493 children of age 2-4 years and 2,526 children of age 5-10 years reported an association for the highest quartiles of milk consumption and BMI in contrast to other dairy products, which had no effect on BMI [77]. It is of critical concern that increased prepregnancy BMI represents an important risk factor for increased birth weight of the offspring [21,22,25].

\section{Milk consumption and gestational weight gain}

Women with large for gestational age (LGA) newborns had an increased BMI before pregnancy $\left(25 \mathrm{~kg} / \mathrm{m}^{2}\right)$, an increased gestational weight gain of $19.0 \mathrm{~kg}$ in comparison to women with a normal BMI before pregnancy of $22.4 \mathrm{~kg} / \mathrm{m}^{2}$ exhibiting a gestational weight gain of $15.8 \mathrm{~kg}$, respectively [85]. Intriguingly, pregnant women gaining excessive weight in comparison to women with optimal weight gain reported a twofold intake of dairy products of about $200 \mathrm{~g} /$ day [86]. Of all dairy products, the strongest predictor of increased maternal weight gain during the last trimester of pregnancy was milk [86]. Thus, milk consumption during pregnancy may increase gestational weight gain.

\section{Milk consumption and placental weight}

Data from 50117 mother-infant pairs of the Danish National Birth Cohort collected from 1996-2002 showed a placental weight increase across the whole range of milk intake [87]. A linear increment of placental weight from $13.3 \mathrm{~g}$ (0-1 glass of milk/day) to $26.4 \mathrm{~g}$ ( $>6$ glasses of milk/day) $(\mathrm{p}<0.001)$ has been reported [87]. A prospective study in India reported that the frequency of milk consumption at 18th week of gestation was positively associated with an increase of placental weight [88].

A milk-induced increase in placental weight may not only raise the nutrient transfer to the fetus but may also increase the amount of placenta-derived growth hormones that impair maternal insulin sensitivity, thereby enhancing maternal blood glucose levels leading to fetal overgrowth and increased birth weight. In fact, maternal blood levels of human placental lactogen (HPL) are correlated with placental weight [89-91], and fetal weight [91-94], respectively. CSH1, the predominant transcript of HPL, is increased in placentas of LGA pregnancies [95]. A link between fetal growth velocity in the second half of the pregnancy and maternal serum HPL levels has been demonstrated [96]. In LGA newborns the expression of CSH1-1, CSH2-1, and CSHL1-4 mRNA transcripts in placenta was significantly increased compared with appropriate for gestational age (AGA) newborns [85]. Women with LGA newborns had an increased BMI before pregnancy $\left(25 \mathrm{~kg} / \mathrm{m}^{2}\right)$, an increased gestational weight gain $(19 \mathrm{~kg})$, and increased placental weight (777.6 g) compared to AGA newborns associated with a normal maternal BMI before pregnancy of $22.4 \mathrm{~kg} / \mathrm{m}^{2}$, a gestational weight gain of $15.8 \mathrm{~kg}$, and a placental weight of $650 \mathrm{~g}$, respectively [85].

\section{mTORC1 promotes placental nutrient transfer}

The placenta is the nutrient and endocrine system controlling prenatal mTORC1 signaling for appropriate fetal growth $[97,98]$. The syncytiotrophoblast, which highly expresses mTOR [99], represents the transporting epithelium and the primary endocrine cell of the human placenta and functions as an mTORC1-dependent nutrient sensor that plays a unique role in the regulation of fetal growth [100]. It has been demonstrated in cultured primary human trophoblast cells that mTORC1 is regulated by glucose, amino acids, and growth factors [101]. mTORC1 is a positive regulator of placental system A and system $\mathrm{L}$ amino acid transporters, suggesting that trophoblast mTORC1 modulates amino acid transfer across the placenta [100]. Trophoblast mTORC1 activation increases the cell surface density of amino acid transporters and thus links maternal nutrient availability and growth factor signaling to fetal growth by modulating the mTORC1-mediated flux of amino acids across the placenta, a mechanism that finally results fetal overgrowth (Figure 1) [100].

Activation of placental mTORC1 signaling has been observed in association with maternal obesity [102]. In female Albino Wistar rats, maternal overweight increased placental mTOR and fetal growth [103]. Obesity is associated with elevated circulating levels of BCAAs, free palmitate, hyperinsulinemia, and insulin resistance [66-70,104]. Obviously, the metabolomics of obesity with enhanced nutrient and hormonal signals overstimulate trophoblast mTORC1 activity. In fact, in obese women giving birth to LGA newborns, the activity of placental insulin/IGF-1 and mTORC1 signaling was positively correlated with birth weight [103].

In contrast, mTORC1 in the human placenta is downregulated in restricted fetal growth [99]. Furthermore, in pregnant baboons maternal nutrient restriction downregulated placental mTOR, insulin/IGF-1 signaling and nutrient transporters [105].

\section{Milk intake and maternal insulin resistance}

Maternal insulin resistance is a physiologic adaptation of pregnancy that limits maternal glucose uptake to ensure an adequate supply of glucose that is shunted to the growing fetus. Hyperinsulinemia and insulin resistance start to develop in the second half of pregnancy and are 
induced by the placenta-derived growth hormones, placental growth hormone (PGH) and human placental lactogen (HPL). The somatogenic and lactogenic hormones of the placenta and maternal pituitary gland integrate the metabolic adaptations of pregnancy with the demands of fetal and neonatal development. Dysregulation of placental growth hormones in pathologic conditions of pregnancy adversely affects fetal growth and postnatal metabolic function [106]. In addition to promoting growth of maternal tissue, PGH induces maternal insulin resistance and thereby facilitates the mobilization of maternal nutrients for fetal growth. HPL and prolactin increase maternal food intake by induction of central leptin resistance and promote maternal $\beta$-cell expansion and insulin production [106]. Remarkably, milk consumption during pregnancy increased placental weight $[87,88]$, which has been associated with increased maternal serum levels of HPL [89-91]. PGH, which activates the maternal GH receptor (GHR), and HPL, which activates the maternal prolactin receptor (PRLR) both induce signal transducer and activator of transcription 5 (STAT5) [107]. STAT5 promotes the expression of suppressor of cytokine signaling proteins (SOCS) [107]. It is well known that HPL stimulates the Janus-activatedkinase-2 (JAK2)/STAT5 signaling pathway [108-110]. HPL induces SOCS1 and SOCS2 [111]. SOCS1, SOCS3, SOCS6 and SOCS7 are negative regulators of insulin signaling by binding to the insulin receptor (IR), blocking access of signaling intermediates and inhibiting IR tyrosine kinase activity, leading to a reduction of IR-directed phosphorylation of IRS-1 and its downstream events, and by targeting IRS-1 and IRS-2 for proteasomal degradation [112-114]. Increased PGH and HPL signaling via upregulated SOCS expression thus induces SOCSmediated insulin resistance (Figure 1) [112-115].

Overstimulated mTORC1 signaling activates S6K1 $[7,14,116,117]$, which reduces insulin signaling by inhibitory phosphorylation of IRS-1 $[116,117]$. BCAA-mediated insulin resistance is explained by enhanced activation of S6K1 [117-124]. In fact, high intake of milk, but not meat, induces insulin resistance in humans [58].

Milk consumption during pregnancy apparently increases the magnitude of maternal insulin resistance 1) by upregulation of placental HPL-SOCS signaling, and 2) by stimulation of maternal mTORC1-S6K1 signaling (Figure 1). Both pathways in a synergistic manner may enhance the magnitude of maternal insulin resistance, thereby increasing the glucose flux to the fetus.

\section{Milk and FGF21-mediated GLUT1-overexpression}

Placental weight gain, which is related to milk consumption during pregnancy, is associated with increased maternal serum levels of HPL [87-91]. HPL activates downstream JAK2/STAT5 signaling [108-110]. Recently, fibroblast growth factor-21 (FGF21) has been related to insulin resistance, type 2 diabetes mellitus, obesity and the metabolic syndrome $[125,126]$. In comparison to control subjects, plasma FGF21 levels were significantly higher in women with gestational diabetes mellitus (GDM) [127]. Increased mRNA expression of FGF21 has been detected in the placenta of women with GDM [128]. Notably, the FGF21 promoter contains three putative STAT5-binding sites [129]. Increased FGF21 production has been observed in late pregnancy in the mouse [130]. Ectopic activation of hepatic mTORC1 in liver-specific $T s c 1$ knockout mice resulted in enhanced expression of FGF21 [131]. Intriguingly, overexpression of FGF21 in 3 T3-L1 adipocytes upregulated glucose uptake and increased mRNA expression of glucose transporter 1 (GLUT1) [132]. GLUT1 is the primary glucose transporter isoform in the human placenta that increases its expression over gestation [133]. GLUT1 has been localized to both the maternal facing microvillous plasma membrane (MVM) with threefold higher expression as compared to the basal plasma membrane (BM) [134]. In maternal diabetes, the expression of GLUT1 in the BM has been reported to increase $[135,136]$. Moreover, increased BM expression of GLUT1 has been associated with high birth weight of large babies of non-diabetic mothers [137].

Thus, milk-mediated overactivation of mTORC1 via placental overexpression of FGF21 and enhanced HPL/ STAT5-driven placental expression of FGF21 may overstimulate trophoblast GLUT1 expression that increases the diaplacental flux of glucose to the fetus (Figure 1). Alterations of maternal and placental metabolic signaling by milk consumption during pregnancy may thus explain accelerated fetal growth and increased birth weight.

\section{MicroRNA-21 and placental, fetal and adipocyte growth}

Jiang et al. [138] recently reported on aberrant upregulation of microRNA-21 in placental tissue of macrosomia. Importantly, exosomal microRNA-21 is an abundant and consistent microRNA of cow's milk [139]. Notably, human and bovine microRNA-21 stem-loops are identical (www.mirbase.org). Milk has been proposed to function as a metabolic transfection system by transfer of exosomal microRNAs activating mTORC1 signaling of the milk recipient [2]. Milk's exosomal microRNA represent milk's "software" and milk-derived BCAAs milk's "hardware" for activating mTORC1 signaling [2]. In fact, Baier et al. [140] provided evidence that microRNAs of commercial pasteurized cow's milk are absorbed by adult human subjects in biologically meaningful amounts from nutritionally relevant doses of cow's milk and affect gene expression of peripheral blood mononuclear cells, HEK293 kidney cell cultures and mouse livers. Furthermore, they demonstrated that disintegration of milk exosomes 
by ultrasonication abolished the transfer and uptake of milk-derived microRNAs [140]. Notably, in placental tissues target genes of microRNA-21 were involved in JAK-STAT, PI3K-AKT, and mTOR signaling pathways [138]. It is thus conceivable that milk-derived exosomal microRNA-21 may reach the trophoblast cell and contributes to overactivated trophoblast mTORC1 signaling. Critical targets of microRNA-21 are mRNAs of important tumor suppressor proteins involved in upstream and downstream suppression of mTORC1 signaling such as PTEN [141-144], Sprouty1 and Sprouty2 [145-147], and PDCD4 [148-150]. Moreover, microRNA-21 has been shown to induce the cell cycle promoter cyclin D1 in an mTORC1-dependent manner [151]. Supposed that milkderived microRNA-21 reaches the trophoblast cells via systemic circulation of the pregnant milk-consuming mother, PTEN suppression could increase insulin/IGF-1/ PI3K/AKT signaling, which further augments mTORC1 activation (Figure 1). MicroRNA-21-mediated inhibition of Sprouty1 and 2 would amplify RAS-RAF-MEK-ERK signaling, which additionally suppresses TSC2 and thus raises mTORC1 activity. Furthermore, microRNA-21 could stimulate the initiation of translation by repression of PDCD4, which is a suppressor of translation initiation that inhibits the RNA helicase eIF4A [152]. Both, 4E-BP-1 and PDCD4 are crucial regulatory inhibitors of translation initiation and thus of protein synthesis. Activation of the mTORC1 pathway and its substrate kinase S6K1 results in subsequent phosphorylation of 4EBP-1 and PDCD4 that promote eIF4E-eIF4G complex assembly and stimulate mRNA translation [151]. Milk microRNA-21-mediated suppression of PDCD4 expression may further amply translation, which enhances placental and finally fetal overgrowth. Furthermore, microRNA-21 promotes adipogenic differentiation and proliferation of human adipose tissue-derived mesenchymal stem cells $[153,154]$, thus promoting fat mass accretion. It has recently been shown that long-term inhibition of microRNA-21 reduced obesity in $\mathrm{db} / \mathrm{db}$ mice [155].

\section{Milk consumption and fetal and birth weight}

The Generation R Study, a population-based prospective cohort study from fetal life until young adulthood in Rotterdam investigated 3405 mothers during pregnancy [156]. Maternal milk consumption of $>3$ glasses $(450 \mathrm{~mL}$ of milk) per day was associated with greater fetal weight gain in the third trimester of pregnancy, which led to an $88 \mathrm{~g}$ higher birth weight than that with milk consumption of 0 to 1 glass per day [156]. This association was limited to milk, whereas protein intake from nondairy food or cheese was not associated with increased birth weight. A possible explanation for this finding is the presence of biologically active microRNAs in milk and their absence in processed milk products such as cheese.
Compared with the lowest reference category of milk consumption ( $0-1$ glasses/day), maternal milk intakes of $>1-$ 2 glasses/day, 2-3 glasses/day, and $>3$ glasses/day were associated with increased fetal weight gain. Fetal weight gain has been estimated by the procedure of Hadlock et al. [157]. Milk-mediated differences in fetal weight gain appeared from the 20th week onward, but became most evident in the last part of the third trimester [156], a period that is controlled by HLP signaling.

Worldwide studies confirmed an increase of birth weight in relation to milk consumption during pregnancy (Table 1). A retrospective cohort in Sweden reported a birth weight increase of $75 \mathrm{~g}$ and $134 \mathrm{~g}$ in the offspring of mothers consuming $>200 \mathrm{~mL}$ and $1 \mathrm{~L}$ milk daily, respectively [158]. A prospective study in India reported that the frequency of milk consumption at the 18th week of gestation was positively associated with birth weight, birth length, and head circumference [88]. According to a prospective study in Canada, maternal daily consumption of an additional $237 \mathrm{~mL}$ of milk was associated with a $41 \mathrm{~g}$ increase in offspring birth weight [159]. A prospective Australian study in 557 mothers reported that protein intake from dairy products was associated with a higher birth weight of the offspring [160]. In a randomized controlled trial of 72 adolescent pregnant mothers in the USA, 25 mothers were counseled to consume $>4$ servings of dairy products a day, which resulted in a $240 \mathrm{~g}$ higher birth weight compared to the control group [161]. According to a systematic literature review, the majority of studies reported positive associations between milk and/or dairy consumption and birth weight-related outcomes [162].

Table 1 Milk intake increases prepregnancy, gestational, placental, fetal, and birth weight

\begin{tabular}{lll}
\hline $\begin{array}{l}\text { Effect of milk } \\
\text { intake }\end{array}$ & Outcome & Studies [Ref.] \\
\hline $\begin{array}{l}\text { Prepregnancy } \\
\text { weight }\end{array}$ & Increase & Randomized intervention study, Denmark [80] \\
$\begin{array}{l}\text { Gestational } \\
\text { weight gain }\end{array}$ & Increase & Observational study, Iceland [86] \\
Placental & Increase & Danish National Birth Cohort, Denmark [87] \\
weight & Increase & Pune Maternal Nutrition Study, India [88] \\
Fetal weight & Increase & Generation R Study, Netherlands [156] \\
Birth weight & Increase & Generation R Study, Netherlands [156] \\
& Increase & Observational study, Sweden [158] \\
& Increase & Pune Maternal Nutrition Study, India [88] \\
& Increase & Observational study, Canada [159] \\
& Increase & Prospective observational study, Australia [160] \\
& Increase & Randomized controlled trial, USA [161] \\
& Increase & Systematic literature review, Norway [162] \\
\hline
\end{tabular}




\section{Conclusions}

We provided literature evidence supported by translational research that milk consumption increases pregravid, gestational, placental, fetal, and birth weight, respectively (Table 1). The Mater-University Study of Pregnancy and Its Outcomes demonstrated that maternal BMI in comparison to paternal BMI is associated with the BMI of the offspring at ages 5 and 14 years [22]. Based on these data, Lawlor et al. [22] proposed the fetal overnutrition hypothesis of obesity and concluded that nutrient-dependent programming effects during fetal life are responsible for the development of obesity [22].

The central hub of nutrient sensing, growth regulation and anabolism is the kinase mTORC1, which is upregulated in obese subjects and by milk consumption [2,14-17]. Milk is an evolutionary feeding and anabolic programming system controlled by the lactation genome that regulates mTORC1-dependent postnatal growth by donation of mTORC1-activating essential BCAAs and exosomal microRNAs $[2,140]$. The placenta is the natural feeding and programming system controlling mTORC1-dependent fetal growth. No other gravid mammal is simultaneously exposed to lactation-driven as well as placenta-driven mTORC1 signaling, except human beings since the Neolithic revolution boosted after the widespread distribution of refrigerators in the early 1950's allowing daily access to bovine milk. From an anthropological perspective, Wiley [13] concluded that milk consumption by humans is a novel behavior that increases BMI and may induce longlasting adverse effects on human health. In fact, our evidence underlines that milk consumption increases prepregnancy BMI [79-81], gestational [85,86], placental $[87,88]$, fetal [156], and birth weight $[156,158-162]$, respectively. Notably, increased birth weight, is a risk factor for the development of mTORC1-driven diseases of civilization [163-171]. The magnitude of fetal and postnatal mTORC1-signaling apparently determines lifelong axes of metabolic, hypothalamic and immunological programming [172-176].

Intrauterine overnutrition affects the risk of obesity [177-180]. High maternal plasma concentrations of glucose, amino acids and free fatty acids have been implicated to result in permanent changes in appetite control, neuroendocrine functioning, and energy metabolism in the developing fetus, thus leading to obesity later in life [176-179]. Milk consumption provides abundant BCAAs and palmitate, stimulates insulin/IGF-1 signaling, and provides abundant exosomal microRNAs that in a synergistic manner may overstimulate trophoblast mTORC1 activity (Figure 1). Overactivated trophoblast mTORC1 signaling finally explains 1) increased expression of mTORC1-dependent amino acid transporters with enhanced diaplacental flux of amino acids, 2) increased
HPL synthesis with STAT5-promoted induction of maternal insulin resistance thus increasing the glucose flux to the fetus, and 3) increased STAT5/FGF21- and mTORC1/ FGF21-driven trophoblast GLUT1 expression promoting diaplacental glucose transfer to the fetus. Accordingly, fetal cells obtain an excessive supply of glucose and BCAAs. Finally, BCAAs that reach fetal cells overactivate fetal mTORC1 signaling promoting fetal overgrowth [180].

When overactivated mTORC1 signaling persists during the postnatal period by the introduction of artificial high protein formula feeding, lifelong deviations of mTORC1-dependent metabolic, neuroendocrine and immunological programming may result $[181,182]$. In this regard, the worst scenario for mTORC1-dependent perinatal malprogramming is an obese mother, who increases milk consumption during pregnancy, and provides excessive protein by artificial formula feeding [182]. High milk intake during pregnancy and high protein formula feeding may synergistically enhance perinatal mTORC1 signaling explaining the fetal overnutrition hypothesis and the early protein hypothesis [22,174,182]. These two hypotheses converge to a perinatal mTORC1overactivation hypothesis, explaining the adverse effects of increased milk-mediated mTORC1 signaling during the pre- and postnatal period of metabolic programming.

Current dietary recommendations for pregnant women intend to assure sufficient supply of calcium and high quality proteins for the growing fetus. However, there is more and more concern about milk's role as a source of calcium. According to the recent opinion of Harvard School of Public Health milk isn't the only, or even best, source of calcium [183]. There are non-dairy foods including leafy green vegetables, broccoli, beans and tofu that supply high amounts of calcium. These calcium-rich food alternatives have a significant advantage in comparison to milk: they do not overstimulate mTORC1 signaling and most importantly do not transfer biologically active exosomal microRNAs [141].

Therefore, we suggest to re-evaluate dietary recommendations for pregnant women. We appeal to the medical community to define save upper limits for milk consumption during pregnancy, especially for those women who enter gravity with increased BMI. Whereas boiling of milk destroys milk's bioactive microRNAs [184], boiling has no effect on milk-BCAA-mediated mTORC1 activation. Future randomized-controlled clinical studies are needed to better study the effect of dietary interventions based on milk consumption's difference during pregnancy, especially in women who enter pregnancy with overweight or obesity, and the risk of increased birth weight [185]. 


\begin{abstract}
Abbreviations
AAs: Amino acids; AGA: Appropriate for gestational age; BCAA: Branched-chain amino acid; BM: Basal membrane; BMI: Body mass index; 4E-BP-1: Eukaryotic translation initiation factor 4E-binding protein 1; FGF21: Fibroblast growth factor 21; GDH: Glutamate dehydrogenase; GDM: Gestational diabetes mellitus; GHR: Growth hormone receptor; GIP: Glucose-dependent insulinotropic polypeptide; GLP-1: Glucagon-like peptide-1; HPL: Human placental lactogen; IGF-1: Insulin-like growth factor-1; IGF1R: Insulin-like growth factor-1 receptor; IR: Insulin receptor; IRS: Insulin receptor substrate; JAK: Janus-activated kinase; PI3K: Phosphoinositide-3 kinase; LAT: L-type amino acid transporter; Leu: Leucine; LGA: Large for gestational age; MicroRNA: Micro-ribonucleic acid; mTORC1: Mechanistic target of rapamycin complex 1; MVM: Microvillous plasma membrane; PGH: Placental growth hormone; PRLR: Prolactin receptor; PTEN: Phosphatase and tensin homolog; RHEB: RAS homolog enrich in brain; S6K1: Ribosomal protein S6 kinase, 70-kD kinase 1; SOCS: Suppressor of cytokine signaling; TSC2: Tuberin.
\end{abstract}

\section{Competing interests}

The authors declare that they have no competing interests.

\section{Authors' contributions}

BCM was responsible for translational research and data abstraction. All authors performed and contributed to literature search, reviewed and edited the manuscript. All authors read and approved the final manuscript.

\section{Acknowledgements}

We would like to thank Gerda Sternecker and Daniela Wagenknecht for the acquisition of literature.

\section{Author details}

${ }^{1}$ Department of Dermatology, Environmental Medicine and Health Theory, University of Osnabrück, Sedanstrasse 115, D-49090 Osnabrück, Germany. ${ }^{2}$ Institute of Clinical Chemistry and Laboratory Medicine, University Clinics of Regensburg, Regensburg, Germany.

Received: 23 October 2014 Accepted: 29 December 2014

Published online: 16 January 2015

\section{References}

1. The American College of Obstetricians and Gynecologists: FAQ1. Nutrition during pregnancy. Sep 2013; http://www.acog.org/ /media/For\%20Patients/ faq001.Pdf?dmc=1\&ts=20140823T1014147121.

2. Melnik BC, John SM, Schmitz G. Milk is not just food but most likely a genetic transfection system activating mTORC1 for postnatal growth. Nutr J. 2013;12:103.

3. Foster KG, Fingar DC. Mammalian target of rapamycin (mTOR): conducting the cellular signaling symphony. J Biol Chem. 2010;285:14071-7.

4. Inoki K, Ouyang H, Li Y, Guan KL. Signaling by target of rapamycin proteins in cell growth control. Microbiol Mol Biol Rev. 2005;69:79-100.

5. Avruch J, Long X, Ortiz-Vega S, Rapley J, Papageorgiou A, Dai N. Amino acid regulation of TOR complex 1. Am J Physiol Endocrinol Metab. 2009;296:E592-602.

6. Sengupta S, Peterson T, Sabatini DM. Regulation of the mTOR complex 1 pathway by nutrients, growth factors, and stress. Mol Cell. 2010;40:310-22.

7. Laplante M, Sabatini DM. mTOR signaling. Cold Spring Harb Perspect Biol. 2012; 4.

8. Kim J, Guan KL. Amino acid signaling in TOR activation. Annu Rev Plant Physiol Plant Mol Biol. 2011;80:1001-32.

9. Kim S, Buel GR, Blenis J. Nutrient regulation of the mTOR complex 1 signaling pathway. Mol Cells. 2013;35:463-73.

10. Jewell JL, Guan KL. Nutrient signaling to mTOR and cell growth. Trends Biochem Sci. 2013;38:233-42.

11. Efeyan A, Sabatini DM. Nutrients and growth factors in mTORC1 activation. Biochem Soc Trans. 2013:41:902-5.

12. Laplante $M$, Sabatini DM. Regulation of $m T O R C 1$ and its impact on gene expression at a glance. J Cell Sci. 2013;126:1713-9.

13. Wiley AS. Cow milk consumption, insulin-like growth factor-l, and human biology: a life history approach. Am J Hum Biol. 2012;24:130-8.

14. Yamin HB, Barnea M, Genzer Y, Chapnik N, Froy O. Long-term commercial cow's milk consumption and its effects on metabolic parameters associated with obesity in young mice. Mol Nutr Food Res. 2014;58:1061-8.
15. Zoncu R, Efeyan A, Sabatini DM. mTOR: from growth signal integration to cancer, diabetes and ageing. Nature Rev Mol Cell Biol. 2011;12:21-35.

16. Johnson SC, Rabinovitch PS, Kaeberlein M. mTOR is a key modulator of ageing and age-related disease. Nature. 2013;493:338-45.

17. Xu S, Cai Y, Wei Y. mTOR signaling from cellular senescence to organismal aging. Aging Dis. 2014;5:263-73.

18. Symonds ME, Mendez MA, Meltzer HM, Koletzko B, Godfrey K, Forsyth S, et al. Early life nutritional programming of obesity: mother-child cohort studies. Ann Nutr Metab. 2013;62:137-45.

19. Abrams BF, Laros Jr RK. Prepregnancy weight, weight gain, and birth weight Am J Obstet Gynecol. 1986;154:503-9.

20. O'Callaghan MJ, Williams GM, Andersen MJ, Bor W, Najman JM. Prediction of obesity in children at 5 years: a cohort study. J Paediatr Child Health. 1997:33:311-6.

21. Li C, Kaur H, Choi WS, Huang TT, Lee RE, Ahluwalia JS. Additive interactions of maternal prepregnancy BMI and breast-feeding on childhood overweight. Obes Res. 2005;13:362-71.

22. Lawlor DA, Smith GD, O'Callaghan M, Alati R, Mamun AA, Williams GM, et al. Epidemiologic evidence for the fetal overnutrition hypothesis: findings from the Mater-University Study of Pregnancy and its Outcomes. Am J Epidemiol. 2007;165:418-24.

23. Davey Smith G, Steer C, Leary S, Ness A. Is there an intrauterine influence on obesity? Evidence from parent child associations in the Avon Longitudinal Study of Parents and Children (ALSPAC). Arch Dis Child. 2007;92:876-80.

24. Viswanathan M, Siega-Riz AM, Moos MK, Deierlein A, Mumford S, Knaack J, et al. Outcomes of maternal weight gain. Evid Rep Technol Assess (Full Rep). 2008;168:1-223.

25. Catalano PM, Farrell K, Thomas A, Huston-Presley L, Mencin P, de Mouzon SH, et al. Perinatal risk factors for childhood obesity and metabolic dysregulation. Am J Clin Nutr. 2009:90:1303-13.

26. Jääskeläinen A, Pussinen J, Nuutinen $\mathrm{O}$, Schwab U, Pirkola J, Kolehmainen M, et al. Intergenerational transmission of overweight among Finnish adolescents and their parents: a 16-year follow-up study. Int J Obes (Lond). 2011;35:1289-94.

27. Wang X, Proud CG. Nutrient control of mTORC1, a cell-cycle regulator. Trends Cell Biol. 2009;19:260-7.

28. Chakrabarti P, English T, Shi J, Smas CM, Kandror KV. Mammalian target of rapamycin complex 1 suppresses lipolysis, stimulates lipogenesis, and promotes fat storage. Diabetes. 2010;59:775-81.

29. Ricoult SJ, Manning BD. The multifaceted role of mTORC1 in the control of lipid metabolism. EMBO Rep. 2013;14:242-51.

30. Howell JJ, Ricoult SJ, Ben-Sahra I, Manning BD. A growing role for mTOR in promoting anabolic metabolism. Biochem Soc Trans. 2013;41:906-12.

31. $\mathrm{Xu} \mathrm{J,} \mathrm{Ji} \mathrm{J,} \mathrm{Yan} \mathrm{XH.} \mathrm{Cross-talk} \mathrm{between} \mathrm{AMPK} \mathrm{and} \mathrm{mTOR} \mathrm{in} \mathrm{regulating} \mathrm{energy}$ balance. Crit Rev Food Sci Nutr. 2012;52:373-81.

32. Shaw RJ, Kosmatka M, Bardeesy N, Hurley RL, Witters LA, DePinho RA, et al. The tumor suppressor LKB1 kinase directly activates AMP-activated kinase and regulates apoptosis in response to energy stress. Proc Natl Acad Sci U S A. 2004;101:3329-35.

33. Dodd KM, Tee AR. Leucine and mTORC1: a complex relationship. Am J Physiol Endocrinol Metab. 2012;302:E1329-42.

34. Nicklin P, Bergman $\mathrm{P}$, Zhang B, Triantafellow $\mathrm{E}$, Wang $\mathrm{H}$, Nyfeler B, et al. Bidirectional transport of amino acids regulates $\mathrm{MTOR}$ and autophagy. Cell. 2009;136:521-34.

35. Cohen A, Hall MN. An amino acid shuffle activates mTORC1. Cell. 2009:136:399-400.

36. Duran RV, Oppliger W, Robitaille AM, Heiserich L, Skendaj R, Gottlieb E, et al. Glutaminolysis activates Rag-mTORC1 signaling. Mol Cell. 2012:47:349-58.

37. Yasuda M, Tanaka Y, Kume S, Morita Y, Chin-Kanasaki M, Araki H, et al. Fatty acids are novel nutrient factors to regulate MTORC1 lysosomal localization and apoptosis in podocytes. Biochim Biophys Acta. 2014;1842:1097-108.

38. Millward DJ, Layman DK, Tomé D, Schaafsma G. Protein quality assessment: impact of expanding understanding of protein and amino acid needs for optimal health. Am J Clin Nutr. 2008;87:1576S-81S.

39. Boirie $Y$, Dangin $M$, Gachon $P$, Vasson MP, Maubois JL, Beaufrère B. Slow and fast dietary proteins differently modulate postprandial protein accretion. Proc Natl Acad Sci U S A. 1997:94:14930-5.

40. He T, Giuseppin ML. Slow and fast dietary proteins differentially modulate postprandial metabolism. Int J Food Sci Nutr. 2014;65:386-90.

41. Boutrou R, Gaudichon C, Dupont D, Jardin J, Airinei G, Marsset-Baglieri A, et al. Sequential releases of milk protein-derived bioactive peptides in the jejunum in healthy humans. Am J Clin Nutr. 2013;97:1414-23. 
42. Mahé S, Roos N, Benamouzig R, Davin L, Luengo C, Gagnon L, et al. Gastrojejunal kinetics and the digestion of [15 N]beta-lactoglobulin and casein in humans: the influence of the nature and quantity of the protein. Am J Clin Nutr. 1996;63:546-52.

43. Lenders CM, Liu S, Wilmore DW, Sampson L, Dougherty LW, Spiegelman D, et al. Evaluation of a novel food composition database that includes glutamine and other amino acids derived from gene sequencing data. Eur J Clin Nutr. 2009:63:1433-9.

44. Li M, Li C, Allen A, Stanley CA, Smith TJ. The structure and allosteric regulation of mammalian glutamate dehydrogenase. Arch Biochem Biophys. 2012;519:69-80.

45. Lorin S, Tol MJ, Bauvy C, Strijland A, Poüs C, Verhoeven AJ, et al. Glutamate dehydrogenase contributes to leucine sensing in the regulation of autophagy. Autophagy. 2013;9:850-60.

46. Xu G, Kwon G, Cruz WS, Marshall CA, McDaniel ML. Metabolic regulation by leucine of translation initiation through the mTOR-signaling pathway by pancreatic beta-cells. Diabetes. 2001;50:353-60.

47. Holt S, Brand Miller J, Petocz P. An insulin index of foods: the insulin demand generated by $1000-k K$ portions of common foods. Am J Clin Nutr. 1997;66:1264-76

48. Hoyt G, Hickey MS, Cordain L. Dissociation of the glycaemic and insulinaemic responses to whole and skimmed milk. Br J Nutr. 2005;93:175-7.

49. Hoppe C, Mølgaard C, Dalum C, Vaag A, Michaelsen KF. Differential effects of casein versus whey on fasting plasma levels of insulin, IGF-1 and IGF-1/IGFBP-3: results from a randomized 7-day supplementation study in prepubertal boys. Eur J Clin Nutr. 2009;63:1076-83.

50. Thomas FB, Sinar D, Mazzaferri EL, Cataland S, Mekhjian HS, Caldwell JH, et al. Selective release of gastric inhibitory polypeptide by intraduodenal amino acid perfusion in man. Gastroenterology. 1978;74:1261-5.

51. Chen $\mathrm{Q}$, Reimer RA. Dairy protein and leucine alter GLP-1 release and mRNA of genes involved in intestinal lipid metabolism in vitro. Nutrition. 2009;25:340-9.

52. Nilsson M, Stenberg M, Frid AH, Holst JJ, Björck IM. Glycemia and insulinemia in healthy subjects after lactose-equivalent meals of milk and other food proteins: the role of plasma amino acids and incretins. Am J Clin Nutr. 2004;80:1246-53.

53. Nilsson M, Holst JJ, Björck IM. Metabolic effects of amino acid mixtures and whey protein in helathy subjects: studies using glucose-equivalent drinks. Am J Clin Nutr. 2007;85:996-1004.

54. Salehi A, Gunnerud U, Muhammed SJ, Ostman E, Holst JJ, Björck I, et al. The insulinogenic effects of whey protein is partially mediated by a direct effect of amino acids and GIP on $\beta$-cells. Nutr Metab (Lond). 2012;9:48.

55. McDaniel ML, Marshall CA, Pappan KL, Kwon G. Metabolic and autocrine regulation of the mammalian target of rapamycin by pancreatic $\beta$-cells. Diabetes. 2002;51:2877-85.

56. Yang J, Chi Y, Burkhardt BR, Guan Y, Wolf BA. Leucine metabolism in regulation of insulin secretion from pancreatic beta cells. Nutr Rev. 2010;68:270-9.

57. Le Bacquer O, Queniat G, Gmyr V, Kerr-Conte J, Lefebvre B, Pattou F. mTORC1 and $\mathrm{mTORC2}$ regulate insulin secretion through Akt in INS-1 cells. J Endocrinol. 2013;216:21-9.

58. Hoppe C, Mølgaard C, Vaag A, Barkholt V, Michaelsen KF. High intakes of milk, but not meat, increases s-insulin and insulin resistance in 8-year-old boys. Eur J Clin Nutr. 2005;59:393-8.

59. Qin LQ, He K, Xu JY. Milk consumption and circulating insulin-like growth factor-I level: a systematic literature review. Int J Food Sci Nutr. 2009;60 Suppl 7:330-40.

60. Norat T, Dossus L, Rinaldi S, Overvad K, Grønbaek H, Tjønneland A, et al. Diet, serum insulin-like growth factor-I and IGF-binding protein-3 in European women. Eur J Clin Nutr. 2007;61:91-8.

61. Rich-Edwards JW, Ganmaa D, Pollak MN, Nakamoto EK, Kleinman K, Tserendolgor $\mathrm{U}$, et al. Milk consumption and the prepubertal somatotropic axis. Nutr J. 2007;6:28.

62. Larnkjær A, Arnberg K, Michaelsen KF, Jensen SM, Mølgaard C. Effect of milk proteins on linear growth and IGF variables in overweight adolescents. Growth Horm IGF Res. 2014;24:54-9.

63. Melnik BC. Leucine signaling in the pathogenesis of type 2 diabetes and obesity. World J Diabetes. 2012;3:38-53.

64. Jensen RG, Ferris AM, Lammi-Keefe CJ. The composition of milk fat. J Dairy Sci. 1991;74:3228-43.

65. Bitman J, Wood DL. Changes in milk fat phospholipids during lactation. J Dairy Sci. 1990;73:1208-16.

66. She P, Van Horn C, Reid T, Hutson SM, Cooney RN, Lynch CJ. Obesity-related elevations in plasma leucine are associated with alterations in enzymes involved in branched-chain amino acid metabolism. Am J Physiol Endocrinol Metab. 2007;293:E1552-63.

67. Newgard CB, An J, Bain J, Muehlbauer MJ, Stevens RD, Lien LF, et al. A branched-chain amino acid-related metabolic signature that differentiates obese and lean humans and contributes to insulin resistance. Cell Metab. 2009:9:311-26.

68. Morris C, O'Grada C, Ryan M, Roche HM, Gibney MJ, Gibney ER, et al. The relationship between $\mathrm{BMI}$ and metabolomic profiles: a focus on amino acids. Proc Nutr Soc. 2012;71:634-8.

69. McCormack SE, Shaham O, McCarthy MA, Deik AA, Wang TJ, Gerszten RE, et al. Circulating branched-chain amino acid concentrations are associated with obesity and future insulin resistance in children and adolescents. Pediatr Obes. 2013:8:52-61.

70. Loridan L, Sadeghi-Nejad A, Senior B. Hypersecretion of insulin after the administration of L-leucine to obese children. J Pediatr. 1971;78:53-8.

71. Zhou YP, Grill VE. Long-term exposure of rat pancreatic islets to fatty acids inhibits glucose-induced insulin secretion and biosynthesis through a glucose fatty acid cycle. J Clin Invest. 1994;93:870-6.

72. Dresner A, Laurent D, Marcucci M, Griffin ME, Dufour S, Cline GW, et al. Effects of free fatty acids on glucose transport and IRS-1-associated phosphatidylinositol 3-kinase activity. J Clin Invest. 1999:103:253-9.

73. Unger RH, Clark GO, Scherer PE, Orci L. Lipid homeostasis, lipotoxicity and the metabolic syndrome. Biochim Biophys Acta. 2010;1801:209-14.

74. Um SH, Frigerio F, Watanabe M, Picard F, Joaquin M, Sticker M, et al. Absence of S6K1 protects against age- and diet-induced obesity while enhancing insulin sensitivity. Nature. 2004;431:200-5.

75. Um SH, D'Alessio D, Thomas G. Nutrient overload, insulin resistance, and ribosomal protein S6 kinase 1, S6K1. Cell Metab. 2006;3:393-402.

76. Hoppe C, Mølgaard C, Michaelsen KF. Cow's milk and linear growth in industrialized and developing countries. Ann Rev Nutr. 2006;26:131-73.

77. Wiley AS. Dairy and milk consumption and child growth: Is BMI involved? An analysis of NHANES 1999-2004. Am J Hum Biol. 2010;22:517-25.

78. Berkey CS, Rocket HR, Willet WC, Colditz GA. Milk, dairy fat, dietary calcium, and weight gain. Arch Pediatr Adolesc Med. 2005;159:543-50.

79. Matthews VL, Wien M, Sabaté J. The risk of child and adolescent overweight is related to types of food consumed. Nutr J. 2011;10:71.

80. Arnberg K, Mølgaard C, Michaelsen KF, Jensen SM, Trolle E, Larnkjær A. Skim milk, whey, and casein increase body weight and whey and casein increase plasma C-peptide concentration in overweight adolescents. J Nutr. 2012;142:2083-90.

81. Barr SI, McCarron DA, Heaney RP, Dawson-Hughes B, Berga SL, Stern JS, et al. Effects of increased consumption of fluid milk on energy and nutrient intake, body weight, and cardiovascular risk factors in healthy older adults. Am J Diet Assoc. 2000;100:810-7.

82. Chen M, Pan A, Malik VS, Hu FB. Effects of dairy intake on body weight and fat: a meta-analysis of randomized controlled trials. Am J Clin Nutr. 2012;96:735-47.

83. Abreu S, Santos R, Moreira C, Vale S, Santos PC, Soares-Miranda L, et al. Association between dairy product intake and abdominal obesity in Azorean adolescents. Eur J Clin Nutr. 2012;66:830-5.

84. Abreu S, Santos R, Moreira C, Santos PC, Vale S, Soares-Miranda L, et al. Milk intake is inversely related to body mass index and body fat in girls. Eur $J$ Pediatr. 2012;171:1467-74.

85. Männik J, Vaas P, Rull K, Teesalu P, Laan M. Differential placental expression profile of human growth hormone/chorionic somatomammotropin genes in pregnancies with pre-eclampsia and gestational diabetes mellitus. Mol Cell Endocrinol. 2012;355:180-7

86. Olafsdottir AS, Skuladottir GV, Thorsdottir I, Hauksson A, Steingrimsdottir L. Maternal diet in early and late pregnancy in relation to weight gain. Int J Obes (Lond). 2006;30:492-9.

87. Olsen SF, Halldorsson TI, Willett WC, Knudsen VK, Gillman MW, Mikkelsen TB, et al. Milk consumption during pregnancy is associated with increased infant size at birth: prospective cohort study. Am J Clin Nutr. 2007:86:1104-10.

88. Rao S, Yajnik CS, Kanade A, Fall CH, Margetts BM, Jackson AA, et al. Intake of micronutrient-rich foods in rural Indian mothers is associated with the size of their babies at birth: Pune Maternal Nutrition Study. J Nutr. 2001;131:1217-24.

89. Cramer DW, Beck P, Makowski EL. Correlation of gestational age with maternal human chorionic somatomammotropin and maternal and fetal growth hormone plasma concentrations during labor. Am J Obstet Gynecol. 1971;109:649-55.

90. Lindberg BS, Nilsson BA. Human placental lactogen (HPL) levels in abnormal pregnancies. J Obstet Gynaecol Br Commonw. 1973;80:1046-53. 
91. Sciarra JJ, Sherwood LM, Varma AA, Lundberg WB. Human placental lactogen (HPL) and placental weight. Am J Obstet Gynecol. 1968;101:413-6.

92. Boyce A, Schwartz D, Hubert C, Cedard L, Dreyfus J. Smoking, human placental lactogen and birth weight. Br J Obstet Gynaecol. 1975;82:964-7.

93. Letchworth AT, Boardman RJ, Bristow C, Landon J, Chard T. A rapid semi-automated method for the measurement of human chorionic sommatomammotrophin. The normal range in the third trimester and its relation to fetal weight. J Obstet Gynaecol Br Commonw. 1971;78:542-8.

94. Lindberg BS, Nilsson BA. Variations in maternal plasma levels of human placental lactogen (HPL) in normal pregnancy and labour. J Obstet Gynaecol Br Commonw. 1973;80:619-26.

95. Freemark M. Placental hormones and the control of fetal growth. J Clin Endocrinol Metab. 2010;95:2054-7.

96. Henleigh PA, Cheatum SG, Spellacy WN. Oxytocinase and human placental lactogen for the prediction of intrauterine growth retardation. Am J Obstet Gynaecol. 1977;129:675-8.

97. Lager S, Oowell TL. Regulation of nutrient transport across the placenta. J Pregnancy. 2012;2012:179827.

98. Larqué E, Riuz-Palacios M, Koletzko B. Placental regulation of fetal nutrient supply. Curr Opin Clin Nutr Metab Care. 2013;16:292-7.

99. Roos S, Jansson N, Palmberg I, Säljö K, Powell TL, Jansson T. Mammalian target of rapamycin in the human placenta regulates leucine transport and is down-regulated in restricted growth. J Physiol. 2007;582:449-59.

100. Jansson T, Aye IL, Goberdhan DC. The emerging role of mTORC1 signaling in placental nutrient-sensing. Placenta. 2012;33 Suppl 2:e23-9.

101. Roos S, Lagerlöf O, Wennergren M, Powell TL, Jansson T. Regulation of amino acid transporters by glucose and growth factors in cultured primary human trophoblast cells is mediated by mTOR signaling. Am J Physiol Cell Physiol. 2009;297:C723-31.

102. Jansson N, Rosario FJ, Gaccioli F, Lager S, Jones HN, Roos S, et al. Activation of placental mTOR signaling and amino acid transporters in obese women giving birth to large babies. J Clin Endocrinol Metab. 2013;98:105-13.

103. Gaccioli F, White V, Capobianco E, Powell TL, Jawerbaum A, Jansson T. Maternal overweight induced by a diet with high content of saturated fat activates placental mTOR and elF2alpha signaling and increases fetal growth in rats. Biol Reprod. 2013;89:96

104. Lu Y, Qian L, Zhang Q, Chen B, Gui L, Huang D, et al. Palmitate induces apoptosis in mouse aortic endothelial cells and endothelial dysfunction in mice fed high-calorie and high-cholesterol diets. Life Sci. 2013;92:1165-73.

105. Kavitha JV, Rosario FJ, Nijland MJ, McDonald TJ, Wu G, Kanai Y, et al. Down-regulation of placental mTOR, insulin/IGF-I signaling, and nutrient transporters in response to maternal nutrient restriction in the baboon. FASEB J. 2014;28:1294-2305.

106. Newbern D, Freemark M. Placental hormones and the control of maternal metabolism and fetal growth. Curr Opin Endocrinol Diabetes Obes. 2011;18:409-16.

107. Hennighausen L, Robibson GW. Interpretation of cytokine signalling through the transcription factors STAT5A and STAT5B. Genes Dev. 2008;22:711-21.

108. Cao J, Gowri PM, Ganguly TC, Wood M, Hyde JF, Talamantes F, et al. PRL, placental lactogen, and $\mathrm{GH}$ induce $\mathrm{NA}(+)$ /taurocholate-cotransporting polypeptide gene expression by activating signal transducer and activator of transcription-5 in liver cells. Endocrinology. 2001;142:4212-22.

109. Kondegowda NG, Mozar A, Chin C, Otero A, Garcia-Ocana A, Vasavada RC. Lactogens protect rodent and human beta cells agianst glucolipotoxicityinduced cell death through Janus kinase-2 (JAK2)/signal transducer and activator of transcription-5 (STAT5) signalling. Diabetologica. 2012;55:1721-32.

110. Fujinaka Y, Takane K, Yamashita H, Vasavada RC. Lactogens promote beta cell survival through JAK2/STAT5 activation and BCl-XL upregulation. J Biol Chem. 2007:282:30707-17.

111. Pedersen NG, Juul A, Chrisitansen M, Wojdemann KR, Tabor A. Maternal serum placental growth hormone, but not human placental lactogen or insulin growth factor-1, is positively associated with fetal growth in the first half of pregnancy. Ultrasound Obstet Gynecol. 2010;36:534-41.

112. Howard JK, Flier JS. Attenuation of leptin and insulin signaling by SOCS proteins. Trends Endocrinol Metab. 2006;17:365-71.

113. Lebrun $P$, Van Obberghen E. SOCS proteins causing trouble in insulin action. Acta Physiol (Oxf). 2008;192:29-36.

114. Lebrun P, Cognard E, Gontard P, Bellon-Paul R, Filloux C, Berthault MF, et al. The suppressor of cytokine signalling 2 (SOCS2) is a key repressor of insulin secretion. Diabetologia. 2010;53:1935-46.
115. Yang Z, Hulver M, McMillan RP, Cai L, Kershaw EE, Yu L, et al. Regulation of insulin and leptin signaling by muscle suppressor of cytokine signaling 3 (SOCS3). PLoS One. 2012;7:e47493.

116. Dann SG, Selvaraj A, Thomas G. mTOR Complex1-S6K1 signaling: at the crossroads of obesity, diabetes and cancer. Trends Mol Med. 2007;13:252-9.

117. Magnuson B, Ekim B, Fingar DC. Regulation and function of ribosomal protein $\mathrm{S} 6$ kinase $(\mathrm{S} 6 \mathrm{~K})$ within mTOR signalling networks. Biochem J. 2012:441:1-21.

118. Patti ME, Brambilla E, Luzi L, Landaker EJ, Kahn CR. Bidirectional modulation of insulin action by amino acids. J Clin Invest. 1998;101:1519-29.

119. Krebs M, Krssak M, Bernroider E, Anderwald C, Brehm A, Meyerspeer M, et al. Mechanism of amino acid-induced skeletal muscle insulin resistance in humans. Diabetes. 2002;51:599-605.

120. Tremblay F, Krebs M, Dombrowski L, Brehm A, Bernroider E, Roth E, et al. Overactivation of $\mathbf{S 6}$ kinase 1 as a cause of human insulin resistance during increased amino acid availability. Diabetes. 2005;54:2674-84.

121. Tremblay F, Brulé S, Hee Um S, Masuda K, Roden M, Sun XJ, et al. Identification of Ser-1101 as a target of S6K1 in nutrient- and obesityinduced insulin resistance. Proc Natl Acad Sci U S A. 2007;104:14056-61.

122. Shah OJ, Wang Z, Hunter T. Inappropriate activation of the TSC/Rheb/ mTOR/S6K cassette induces IRS1/2 depletion, insulin resistance, and cell survival deficiencies. Curr Biol. 2004;14:1650-6.

123. Lu J, Xie G, Jia W, Jia W. Insulin resistance and the metabolism of branchedchain amino acids. Front Med. 2013;7:53-9.

124. Zeng M, Che Z, Liang Y, Wang B, Chen X, Li H, et al. GC-MS based plasma metabolic profiling of type 2 diabetes mellitus. Chromatographia. 2009;69:941-8.

125. Iglesias P, Selgas R, Romero S, Díez JJ. Biological role, clinical significance, and therapeutic possibilities of the recently discovered metabolic hormone fibroblastic growth factor 21. Eur J Endocrinol. 2012;167:301-9.

126. Zhang X, Yeung DC, Karpisek M, Stejskal D, Zhou ZG, Liu F, et al. Serum FGF21 levels are increased in obesity and are independently associated with the metabolic syndrome in humans. Diabetes. 2008:57:1246-53.

127. Tan BK, Sivakumar K, Bari MF, Vatish M, Randeva HS. Lower cerebrospinal fluid/plasma fibroblast growth factor 21 (FGF21) ratios and placental FGF2 production in gestational diabetes. PLoS One. 2013;8:e65254.

128. Dekker Nitert M, Barrett HL, Kubala MH, Scholz Romero K, Denny KJ, Woodruff TM, et al. Increased placental expression of fibroblast growth factor 21 in gestational diabetes mellitus. J Clin Endocrinol Metab. 2014;99:E591-8.

129. Yu J, Zhao L, Wang A, Eleswarapu S, Ge X, Chen D, et al. Growth hormone stimulates transcription of the fibroblast growth factor 21 gene in the liver through the signal transducer and activator of transcription 5. Endocrinology. 2012;153:750-8.

130. Cui Y, Giesy SL, Hassan M, Davis K, Zhao S, Boisclair YR. Hepatic FGF21 production is increased in late pregnancy in the mouse. Am J Physiol Regul Integr Comp Physiol. 2014;307:R290-8.

131. Cornu M, Oppliger W, Albert V, Robitaille AM, Trapani F, Quagliata L, et al. Hepatic mTORC1 controls locomotor activity, body temperature and lipid metabolism through FGF21. Proc Natl Acad Sci U S A. 2014;111:11592-9.

132. Li K, Li L, Yang M, Liu H, Boden G, Yang G. The effects of fibroblast growth factor-21 knockdown and over-expression on its signaling pathway and glucose-lipid metabolism in vitro. Mol Cell Endocrinol. 2012:348:21-6.

133. Ericsson A, Hamark B, Powell TL, Jansson T. Glucose transporter isoform 4 is expressed in the syncytiotrophoblast of first trimester human placenta. Hum Reprod. 2005;20:521-30.

134. Jansson T, Wennergren M, Illsley NP. Glucose transporter protein expression in human placenta throughout gestation and in intrauterine growth retardation. J Clin Endocrinol Metab. 1993;77:1554-62

135. Jansson T, Wennergren M, Powell TL. Placental glucose transport and GLUT1 expression in insulin-dependent diabetes. Am J Obstet Gynecol. 1999;180:163-8.

136. Gaither K, Quraishi AN, Illsley NP. Diabetes alters the expression and activity of the human placental GLUT1 glucose transporter. J Clin Endocrinol Metab. 1999:84:695-701.

137. Acosta O, Ramirez VI, Lager S, Gaccioli F, Dudley DJ, Powell TL, et al. Increased glucose and placental GLUT-1 in large babies of obese non-diabetic mothers. Am J Obstet Gynecol. 2014; Aug 14 [Epub ahead of print].

138. Jiang H, Wu W, Zhang M, Li J, Peng Y, Miao TT, et al. Aberrant upregulation of miR-21 in placental tissues of macrosomia. J Perinatol. 2014;34:658-63.

139. Chen X, Gao C, Li H, Huang L, Sun Q, Dong Y, et al. Identification and characterization of microRNAs in raw milk during different periods of lactation, commercial fluid, and powdered milk products. Cell Res. 2010;20:1128-37. 
140. Baier SR, Nguyen C, Xie F, Wood JR, Zempleni J. MicroRNAs are absorbed in biologically meaningful amounts from nutritionally relevant doses of cow milk and affect gene expression in peripheral blood mononuclear cells, HEK-293 kidney cell cultures, and mouse livers. J Nutr. 2014;144:1495-500.

141. Meng F, Henson R, Wehbe-Janek H, Ghoshal K, Jacob ST, Patel T. MicroRNA-21 regulates expression of the PTEN tumor suppressor gene in human hepatocellular cancer. Gastroenterology. 2007;133:647-58.

142. Han M, Liu M, Wang Y, Chen X, Xu J, Sun Y, et al. Antagonism of miR-21 reverses epithelial-mesenchymal transition and cancer stem cell phenotype through AKT/ERK1/2 inactivation by targeting PTEN. PLoS One. 2012;7:e39520.

143. Dey N, Das F, Mariappan MM, Mandal CC, Ghosh-Choudhury N, Kasinath BS, et al. MicroRNA-21 orchestrates high glucose-induced signals to TOR complex 1, resulting in renal cell pathology in diabetes. J Biol Chem. 2011;286:25586-603.

144. Dey N, Ghosh-Choudhury N, Kasinath BS, Choudhury GG. TGFß-stimulated microRNA-21 utilizes PTEN to orchestrate AKT/mTORC1 signaling for mesangial cell hypertrophy and matrix expansion. PLoS One. 2012;7:e42316.

145. Sayed D, Rane S, Lypowy J, He M, Chen IY, Vashistha H, et al. MicroRNA-21 targets Sprouty2 and promotes cellular outgrowths. Mol Biol Cell. 2008;19:3272-82.

146. Dariminpourain M, Wang S, Ittmann M, Kwabi-Addo B. Transcriptional and post-transcriptional regulation of Sprouty1, a receptor tyrosine kinase inhibitor in prostate cancer. Prostate Cancer Prostatic Dis. 2011;14:279-85.

147. Frey MR, Carraro G, Batra RK, Polk DB, Warburton D. Sprouty keeps bowel kinases regular in colon cancer, while miR-21 targets Sprouty. Cancer Biol Ther. 2011;11:122-4.

148. Asangani IA, Rasheed SA, Nikolova DA, Leupold JH, Colburn NH, Post S, et al. MicroRNA-21 (miR-21) post-transcriptionally downregulates tumor suppressor Pdcd4 and stimulates invasion, intravasation and metastasis in colorectal cancer. Oncogene. 2008;27:2128-36.

149. Lu Z, Liu M, Stribinskis V, Klinge CM, Ramos KS, Colburn NH, et al. MicroRNA-21 promotes cell transformation by targeting the programmed cell death 4 gene. Oncogene. 2008:27:4373-9.

150. Carayol N, Katsoulidis E, Sassano A, Altman JK, Druker BJ, Platanias LC. Suppression of programmed cell death 4 (PDCD4) protein expression by BCR-ABL-regulated engagement of the mTOR/p70 S6 kinase pathway. J Biol Chem. 2008;28:8601-10.

151. Ng R, Song G, Roll GR, Frandsen NM, Willenbring H. A microRNA-21 surge facilitates rapid cyclin D1 translation and cell cycle progression in mouse liver regeneration. J Clin Invest. 2012;122:1097-108.

152. Dennis MD, Jefferson LS, Kimball SR. Role of p70S6K1-mediated phosphorylation of elF4B and PDCD4 proteins in the regulation of protein synthesis. J Biol Chem. 2012;287:42890-9.

153. Kim YJ, Hwang SJ, Bae YC, Jung JS. MiR-21 regulates adipogenic differentiation through the modulation of TGF-beta signaling in mesenchymal stem cells derived from human adipose tissue. Stem Cells. 2009;27:3093-102.

154. Kim YJ, Hwang SH, Cho HH, Shin KK, Bae YC, Jung JS. MicroRNA 21 regulates the proliferation of human adipose tissue-derived mesenchymal stem cells and high-fat diet-induced obesity alters microRNA 21 expression in white adipose tissues. J Cell Physiol. 2012;227:183-93.

155. Seeger T, Fischer A, Muhly-Reinholz M, Zeiher AM, Dimmeler S. Long-term inhibition of miR-21 leads to reduction of obesity in $\mathrm{db} / \mathrm{db}$ mice. Obesity (Silver Spring). 2014;22:2352-60

156. Heppe DH, van Dam RM, Willemsen SP, den Breeijen H, Raat H, Hofman A, et al. Maternal milk consumption, fetal growth, and the risks of neonatal complications: the Generation R Study. Am J Clin Nutr. 2011;94:501-9.

157. Hadlock FP, Harrist RB, Sharman RS, Deter RL, Park SK. Estimation of fetal weight with the use of head, body, and femur measurements - a prospective study. Am J Obstet Gynecol. 1985;151:333-7.

158. Ludvigsson JF, Ludvigsson J. Milk consumption during pregnancy and infant birthweight. Acta Paediatr. 2004;93:1474-8.

159. Mannion CA, Gray-Donald K, Koski KG. Association of low intake of milk and vitamin D during pregnancy with decreased birth weight. CMAJ. 2006:174:1273-7.

160. Moore VM, Davies MJ, Willson KJ, Worsley A, Robinson JS. Dietary composition of pregnant women is related to size of the baby at birth. J Nutr. 2004;134:1820-6.

161. Chan GM, McElligott K, McNaught T, Gill G. Effects of dietary calcium intervention on adolescent mothers and newborns: A randomized controlled trial. Obstet Gynecol. 2006;108:565-71.

162. Brantsæter AL, Olafsdottir AS, Forsum E, Olsen SF, Thorsdottir I. Does milk and dairy consumption during pregnancy influence fetal growth and infant birthweight? A systematic literature review. Food Nutr Res. 2012:56:20050
163. Boney CM, Verma A, Tucker R, Vohr BR. Metabolic syndrome in childhood: association with birth weight, maternal obesity, and gestational diabetes mellitus. Pediatrics. 2005;115:e290-6.

164. Sørensen HT, Sabroe S, Rothman KJ, Gillman M, Fischer P, Sørensen TI. Relation between weight and length at birth and body mass index in young adulthood: cohort study. BMJ. 1997;315:1137.

165. Leunissen RW, Stijnen T, Hokken-Koelega AC. Influence of birth size on body composition in early adulthood: the programming factors for growth and metabolism (PROGRAM)-study. Clin Endocrinol (Oxf). 2009;70:245-51.

166. Brüske I, Flexeder C, Heinrich J. Body mass index and incidence of asthma in children. Curr Opin Allergy Clin Immunol. 2014;14:155-60.

167. Skilton MR, Siitonen N, Würtz P, Viikari JS, Juonala M, Seppälä I, et al. High birth weight is associated with obesity and increased carotid wall thickness in young adults: the cardiovascular risk in young Finns study. Arterioscler Thromb Vasc Biol. 2014:34:1064-8.

168. Bukowski R, Chlebowski RT, Thune I, Furberg AS, Hankins GD, Malone FD, et al. Birth weight, breast cancer and the potential mediating hormonal environment. PLoS One. 2012;7:e40199.

169. Spracklen CN, Wallace RB, Sealy-Jefferson S, Robinson JG, Freudenheim JL, Wellons MF, et al. Birth weight and subsequent risk of cancer. Cancer Epidemiol. 2014:38:538-43.

170. Lewis RM, Demmelmair H, Gaillard R, Godfrey KM, Hauguel-de Mouzon S, Huppertz B, et al. The placental exposome: placental determinants of fetal adiposity and postnatal body composition. Ann Nutr Metab. 2013;63:208-15.

171. Yang Z, Huffman SL. Nutrition in pregnancy and early childhood and associations with obesity in developing countries. Matern Child Nutr. 2013:9 Suppl 1:105-19.

172. Haissaguerre M, Saucisse N, Cota D. Influence of mTOR in energy and metabolic homeostasis. Mol Cell Endocrinol. 2014:397:67-77.

173. Melnik BC. The potential mechanistic link between allergy and obesity development and infant formula feeding. Allergy Asthma Clin Immunol. 2014:10:37.

174. Melnik BC. Excessive leucine-mTORC1-signalling of cow milk-based infant formula: The missing link to understand early childhood obesity. J Obes. 2012;2012:197653.

175. Harlan SM, Guo DF, Morgan DA, Fernandes-Santos C, Rahmouni K. Hypothalamic mTORC1 signaling controls sympathetic nerve activity and arterial pressure and mediates leptin effects. Cell Metab. 2013:17:599-606.

176. Villanueva EC, Münzberg H, Cota D, Leshan RL, Kopp K, Ishida-Takahashi R, et al. Complex regulation of mammalian target of rapamycin complex 1 in the basomedial hypothalamus by leptin and nutritional status. Endocrinology. 2009;150:4541-51.

177. Oken E, Gillman MW. Fetal origins of obesity. Obes Res. 2003;11:496-506.

178. Gillman MW. A life course approach to obesity. In: Kuh D, Be-Shlomo Y, editors. A life course approach to chronic disease epidemiology. 2nd ed. New York, NY: Oxford University Press; 2004. p. 189-217.

179. Freinkel N. Banting Lecture 1980. Of pregnancy and progeny. Diabetes. 1980;29:1023-35.

180. Lynch CJ, Adams SH. Branched-chain amino acids in metabolic signalling and insulin resistance. Nat Rev Endocrinol. 2014;10:723-36.

181. Whitaker RC, Dietz WH. Role of the prenatal environment in the development of obesity. J Pediatr. 1998;132:768-76.

182. Melnik BC. Formula feeding promotes adipogenic, diabetogenic, hypertonic and allergic mTORC1-programming. In: Preedy VR, Watson RR, Zibadi S, editors. Handbook of dietary and nutritional aspects of bottle feeding. Human Health Handbooks no. 8, Wageningen Academic Publishers Wageningen. 2014. p. 545-68.

183. Harvard School of Public Health. The Nutrition Source: Calcium and milk http://www.hsph.harvard.edu/nutritionsource/what-should-you-eat/calciumand-milk/.

184. Melnik BC, John SM, Schmitz G. Milk: an exosomal microRNA transmitter promoting thymic regulatory $T$ cell maturation preventing the development of atopy? J Transl Med. 2014;12:43.

185. Dodd JM, McPhee AJ, Turnbull D, Yelland LN, Deussen AR, Grivell RM, et al The effects of antenatal dietary and lifestyle advice for women who are overweight or obese on neonatal health outcomes: the LIMIT randomized trial. BMC Med. 2014;12:163. 